\title{
Recent slowdown and thinning of debris-covered glaciers in south-eastern Tibet
}

\author{
Niklas Neckel ${ }^{\mathrm{a}}$, David Loibl ${ }^{\mathrm{b}, \mathrm{c}}$, Melanie Rankl ${ }^{\mathrm{d}}$ \\ Correspondence to: niklas.neckel@awi.de \\ ${ }^{a}$ Alfred Wegener Institute, Helmholtz Centre for Polar and Marine Research, Am Alten \\ Hafen 26, 27568 Bremerhaven, Germany \\ ${ }^{b}$ Department of Geography, RWTH Aachen University, Templergraben 55, 52062 Aachen, \\ Germany \\ ${ }^{c}$ Geography Department, Humboldt-Universität zu Berlin, Unter den Linden 6, 10099 \\ Berlin, Germany \\ ${ }^{d}$ Institute of Geography, University of Erlangen-Nürnberg, Wetterkreuz 15, 91058 \\ Erlangen, Germany
}

\begin{abstract}
Recent large-scale remote sensing studies have shown that glacier mass loss in south-eastern Tibet, specifically in the eastern Nyainqêntanglha Range exceeds the average in High Asia. However, detailed studies at individual glaciers are scarce and the drivers behind the observed rapid changes are poorly constrained to date. Employing feature tracking techniques on TerraSAR-X data for the periods 2008/2009, 2012/2013 and 2013/2014 we found measurable surface velocities through to the glacier terminus positions of five debris-covered glacier tongues. This is contrary to debris-covered glaciers in other parts of High Asia, where stagnant glacier tongues are common. Our feature tracking results for the 2013/2014 period suggest an average deceleration of $51 \%$ when compared with published Landsat velocities for the period 1999/2003. Further, we estimated surface elevation changes for the five glaciers from recently released one arc second resolution elevation data obtained during the Shuttle Radar Topography Mission in 2000 and an interferometrical derived TanDEM-X elevation model for the year 2014 . With an average rate of $-0.83 \pm 0.57 \mathrm{~m} \mathrm{a}^{-1}$ we confirm strong surface lowering in the region, despite the widely discussed insulation effect of debris cover. Beside the influence of thermokarst processes and delayed response times of debris-covered glaciers, we highlight that abundant monsoonal summer rainfall might contribute significantly to the pronounced negative mass balances
\end{abstract}


in the study region.

Keywords: glacier velocities, glacier elevation changes, debris-covered glaciers, eastern Nyainqêntanglha Range

2

\section{Introduction}

Recent large-scale remote sensing studies based on satellite laser altimetry data and differencing of digital elevation models (DEMs) have shown a heterogeneous pattern of glacier mass changes in High Asia (Gardelle et al., 2013; Neckel et al., 2014; Kääb et al., 2015). While balanced or slightly positive mass balances are evident for parts of the Pamirs and the Karakorum in recent years, pronounced negative glacier mass balances were found in southeastern Tibet, specifically in the eastern Nyainqêntanglha Range. Details about these glaciers' specific response to climate change are, however, scarce, because few local glaciological mass balance measurements exist and multiannual records are lacking. Furthermore, meteorological station records are rare and can not directly be transferred to the glacierized high mountain regions, as most stations are located in inhabited river valleys. Even if glaciers are located in the same climatic environment, local parameters such as catchment aspect, topography and debris cover can have a significant impact on how a specific glacier responses to climate change (Kääb, 2005; Scherler et al., 2011).

The combination of high mountain topography and abundant moisture facilitates $\sim 8000 \mathrm{~km}^{2}$ of glaciated area in the eastern Nyainqêntanglha Range, including some of the largest glaciers in High Asia (Shi et al., 2010; Hochreuther et al., 2015; Loibl et al., 2015). This study focuses on five debris-covered valley glaciers in the central-northern part of the mountain range, specifically in the upper reaches of Lequ Valley and Bodui Valley (Figure 1). Glaciers in the study area are reported to be of temperate type and are influenced by the South Asian monsoon circulation (Shih et al., 1980; Huang, 1990). These glaciers receive most precipitation in summer and/or spring, which falls as snow in their high altitude accumulation areas, resulting in the coincidence of maximum accumulation and ablation phases (Maussion et al., 2014; Loibl et al., 2014). The lower portions of many temperate glaciers in this region are covered by supraglacial debris (Wei et al., 2010). Debris-covered glaciers are known to react differently to warming when compared to clean-ice glaciers, as the debris cover insulates the glacier surface provided a sufficient thickness 
of a few centimeters is reached (Östrem, 1959; Reznichenko et al., 2010). Due to this insulating effect debris-covered glaciers can extend to lower elevations than clean-ice glaciers would in a similar geographic environment (Rowan et al., 2015). However, this insulating effect is well known on local scales, but it remains unclear whether it can be applied to entire glacier tongues (Kääb et al., 2012).

Observations of glacier velocities and surface elevation changes are important parameters to better understand the current state of glaciers and their interaction with changes in regional climate conditions (Cuffey and Paterson, 2010; Paul et al., 2015; Thakuri et al., 2016). In this study, we applied a feature tracking approach based on TerraSAR-X data to derive glacier surface velocities for the periods 2008/2009, 2012/2013 and 2013/2014. The resulting velocity fields were compared to optical remote sensing-based estimates for the period 1999/2003 as published by Dehecq et al. (2015). The velocity fields and their interannual variability were analyzed to investigate glacier dynamics in this key region where no in-situ measurements are available. Further we discuss the differences to other debris-covered glaciers in the Himalayas and on the Tibetan Plateau. Additionally, we employed data from the TerraSAR-X add-on for Digital Elevation Measurement (TanDEM$\mathrm{X})$ mission to calculate recent glacier surface elevations. In order to estimate glacier surface elevation changes between 2014 and 2000 the TanDEM-X elevations were compared to digital elevation data from the Shuttle Radar Topography Mission (SRTM). Here, preference was given to the recently released one arc second version of the dataset. By conducting an integrated analysis of measured glacier velocities and surface elevation changes we investigated spatial and temporal properties of glacier dynamics against the background of the monsoonal climate setting in the study area.

\section{Data and methods}

\subsection{Glacier surface velocities}

Surface velocities between the periods 2008/2009, 2012/2013 and 2013/2014 were derived from intensity/feature tracking on repeat-pass TerraSAR-X satellite imagery (see Rankl et al., 2014, and references therein, for details). Based on the image intensity, this technique tracks surface features and, if coherence is retained, the speckle pattern on a pair of co-registered, single-look complex (SLC) images from two different acquisition dates. The tracking algorithm uses the maximum of cross correlation in a pre-defined moving 


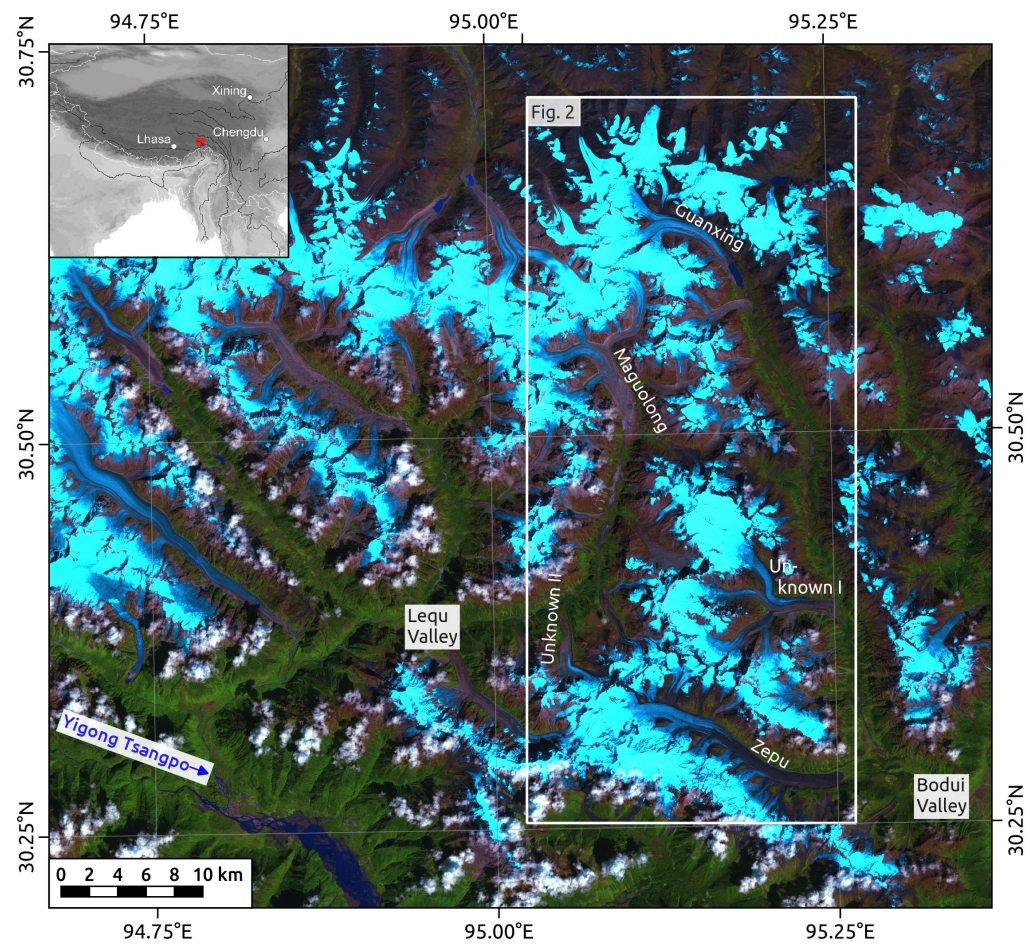

Figure 1: Regional overview of the study area in the eastern Nyainqêntanglha Range, south-eastern Tibet. Location of Figure 2 and the five investigated glaciers are indicated. Background: Landsat-7 ETM+, bands 5-4-3-pan, acquired on 23 September 1999. 
search window. For this, a window size and a step size between patches need to be defined. After testing different search window sizes, we chose a final window size of both 256 pixels in range and azimuth with a step size between patches of 25 pixels in range and azimuth. This setting was found to be most robust considering the long time interval between data acquisitions. Table 1 lists the TerraSAR-X scenes which were used for the synthetic aperture radar (SAR) offset tracking. Surface velocities for the period 1999/2003 are based on Landsat estimates following the method of Dehecq et al. (2015). The velocity field was obtained from a stack of velocities derived from feature tracking on Landsat-7 band 8 image pairs separated by approximately one year. For the final stack, all available Landsat-7 acquisitions over the period 1999/2003 were used (Dehecq et al., 2015, A. Dehecq, personal communication, March 2016).

\subsection{Surface elevation changes}

Surface elevation changes $(\Delta h)$ were calculated between data from the Shuttle Radar Topography Mission (SRTM) acquired in 2000 (Rabus et al., 2003; Farr et al., 2007) and the 2014 TanDEM-X acquisition, which was also employed for the 2013/2014 velocity field (Table 1). Here, we make use of the SRTM C-band DEM with a grid spacing of one arc second, which was recently released by the U.S. Geological Survey (USGS). The TanDEM-X DEM was derived with a similar processing scheme as described by Neckel et al. (2013). In order to minimize unwrapping errors in the processing of the TanDEM-X DEM, phase unwrapping was performed on a differential interferogram. The latter was formed by subtracting the simulated phase of the SRTM DEM from the TanDEM-X interferogram. A remaining phase ramp was removed by applying a 2D quadratic phase model on the unwrapped differential interferogram. The final TanDEM-X DEM was generated by adding back the differential heights to the SRTM DEM. Horizontal offsets between the SRTM DEM and the TanDEM-X DEM were eliminated by using the precise orbit information of the TanDEM-X data and a refinement of the lookup table, which holds the relation between the map coordinates of the SRTM DEM and the matching TanDEM-X master scene available in SAR geometry. The refinement of the lookup table is based on a horizontal coregistration between a simulated SAR image of the SRTM DEM and the TanDEM-X master scene using an intensity cross-correlation algorithm (e.g. Rankl and Braun, 2016).

Our final elevation changes between the SRTM DEM and the TanDEM-X 
DEM were calculated following the approach of Gardelle et al. (2013). This approach is based on the assumption that elevation changes should be similar at a given altitude. Therefore $\Delta h$ values of each glacier were grouped into $100 \mathrm{~m}$ altitude bands. Following Gardelle et al. (2013) outliers were removed, if they deviated by more than three standard deviations from the $\Delta h$ mean of the respective altitude band. In order to calculate average elevation changes for the entire glacier area "no data" values were filled with the cleaned $\Delta h$ mean of the appropriate altitude band.

Glacier DEMs derived by SAR interferometry are potentially biased by penetration effects of the radar waves into snow and ice and hence, might reflect some lower surface than the actual glacier surface (Rignot et al., 2001; Gardelle et al., 2012). This holds true especially in the accumulation area as largest penetration depths can be assumed for snow and firn compared to smaller values for ice (Kääb et al., 2015). Without additional information of the surface characteristics at the time of data acquisition, this bias hardly can be quantified and as a consequence, is widely discussed in the literature (Berthier et al., 2006, 2007; Kääb et al., 2012; Gardelle et al., 2013; Holzer et al., 2015). Here we rely on published values from Kääb et al. (2015) who extrapolated $\Delta h$ trends derived from Ice Cloud and Elevation Satellite (ICESat) measurements to 2000 for several sub-regions in High Asia. Following the estimate of Kääb et al. (2015) for the eastern Nyainqêntanglha Range, we applied a penetration depth correction of $8.5 \pm 1.5 \mathrm{~m}$ in the accumulation area. We considered no radar penetration in the ablation area as the glaciers are extensively debris covered. We did not account for the X-band penetration of TanDEM-X, but assume that it is much smaller when compared to the C-band penetration of SRTM (Gardelle et al., 2012).

\subsection{Glacier areas}

Glacier masks are based on the Landsat estimates from Loibl et al. (2014). Outlines from the original mapping were extended to cover all potentially debris-covered areas, omitting the visual interpretation of stagnant ice areas. This modification was necessary to investigate glaciers as a whole and to evaluate the optical interpretation of stagnant ice areas as described in detail in Loibl and Lehmkuhl (2015). The Landsat-7 ETM+ acquisition from 23 September 1999 remains the only Landsat scene fulfilling the required criteria for appropriate glacier mapping in the frequently cloud and snow covered study area. In order to separate the accumulation and ablation areas of the 
Table 1: Remote sensing datasets used for glacier masks, estimates of the Transient snowline (TSL), $\Delta h$ calculations and feature tracking.

\begin{tabular}{lccc}
\hline Acquisition date & Mission & Relative orbit & Application \\
\hline $1999-09-23$ & Landsat-7 ETM+ & 135 & Glacier masks and TSL \\
$2000-02-11$ & SRTM & - & $\Delta h$ \\
$2008-09-27$ & TerraSAR-X & 135 & Feature tracking \\
$2009-09-03$ & TerraSAR-X & 135 & Feature tracking \\
$2012-07-05$ & TerraSAR-X & 158 & Feature tracking \\
$2013-07-03$ & TerraSAR-X & 158 & Feature tracking \\
$2013-06-26$ & TerraSAR-X & 59 & Feature tracking \\
$2014-06-02$ & TanDEM-X & 59 & Feature tracking and $\Delta h$ \\
\hline
\end{tabular}

five investigated glaciers, we manually delineated the late summer Transient snowline (TSL) for each glacier from the Landsat scene. Debris-covered areas of the five studied glaciers were mapped manually (cf. Figures S2-S5). All area estimates were translated from planimetric areas into surface areas by taking into account the local surface slope obtained from the SRTM DEM (Lopez and Berry, 2002).

\subsection{Data quality and uncertainties}

As the time interval between the TerraSAR-X acquisitions is between 341 and 363 days, no speckle correlation is preserved on clean ice between the data acquisitions due to loss of signal coherence. Similar to results from optical feature tracking, the offset tracking analysis therefore relies on surface structures such as crevasses and debris cover. Any surface motion over structureless, homogeneous areas may be undetectable. Accordingly, the method works particularly well for tongues of large debris-covered valley glaciers as indicated by consistent flow directions in the derived velocity fields (Figures S2-S5). Accumulation areas and steep passages represent major challenges to the method as indicated by arbitrary flow directions in these regions. Therefore we applied an additional directional filter with a threshold of $\pm 20^{\circ}$ between the TerraSAR-X derived surface velocities and the 1999/2003 Landsat velocity field (e.g. Scherler et al., 2008). Additionally, the rugged topography poses challenges to radar data acquisition, i.e. shadowing and layover effects, resulting in striped artifacts and data gaps. The latter also applies for the interferometrically derived TanDEM-X DEM.

Considering the limitations outlined above, the debris-covered tongues of five large valley glaciers showed the most coherent results in terms of surface velocities and elevation changes (Figure 2). Owing their diversity in length, 
altitude, spatial orientation and degree of debris cover, they cover a broad spectrum of glaciers in the wider region (Figure 1).

In order to quantify errors of the derived surface velocity fields, we assume that no motion should be observable in off-glacier regions, i.e. on bedrock. Displacement values collected over these areas were considered erroneous (Copland et al., 2009; Quincey et al., 2011; Rankl et al., 2014; Dehecq et al., 2015; Seehaus et al., 2015). Off-glacier values were defined as all data values located in a $1 \mathrm{~km}$ buffer outside the glacierized area with a surface slope between $0^{\circ}$ and $30^{\circ}$. The latter was chosen as it represents the approximate range of the glacier surface slope in the study area. From these data samples, errors in surface velocities were calculated by (Mcnabb et al., 2012; Seehaus et al., 2015)

$$
e_{v e l}=365 \frac{C \Delta x}{z \Delta t}+\sigma
$$

where $C$ is an uncertainty estimate of the offset tracking algorithm, $\Delta x$ is the SLC image resolution, $z$ is the applied SLC oversampling factor and $\Delta t$ is the time difference between the two data takes employed in the offset tracking. For the 2008/2009, 2012/2013 and 2013/2014 velocity fields, Equation 1 resulted in $\pm 1.07 \mathrm{~m} \mathrm{a}^{-1}, \pm 1.45 \mathrm{~m} \mathrm{a}^{-1}$ and $\pm 5.53 \mathrm{~m} \mathrm{a}^{-1}$, respectively.

The error calculation of the $\Delta h$ grid is based on off-glacier values meeting the same requirements as for the velocity error estimate, i.e. all $\Delta h$ values located in a $1 \mathrm{~km}$ buffer outside the glacierized area with a surface slope between $0^{\circ}$ and $30^{\circ}$ are considered. Here, we calculated the Normalized Median Absolute Deviation (NMAD) of the respective off-glacier data samples (e.g. Höhle and Höhle, 2009). The resulting mean and NMAD are $4.79 \mathrm{~m}$ and $8.07 \mathrm{~m}$ respectively. The final $\Delta h$ grid was corrected for the mean value. For the overall error of the average glacier elevation changes the NMAD and the uncertainty of the radar penetration depth were added in quadrature. For the average $\Delta h$ estimates a certain error due to the filling of "no data" values is introduced, which is difficult to quantify. Here, we argue that our results are within the errors bars when compared to results without filling data gaps in the $\Delta h$ grid.

\section{Results}

The velocity data of the five investigated debris-covered glaciers indicate that their terminus regions are still active. Surface velocities are lowest at the 

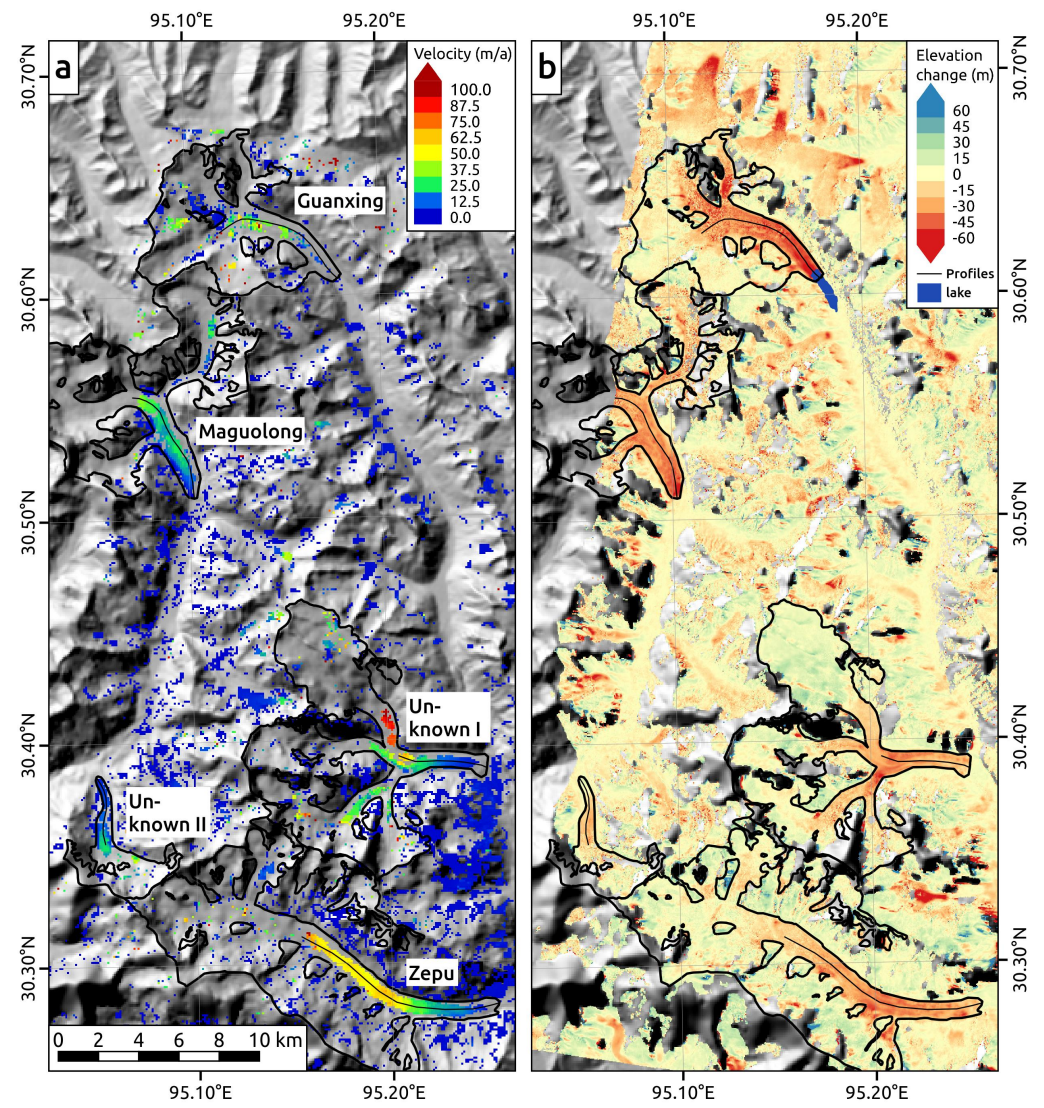

Figure 2: TerraSAR-X feature tracking results between 2013-06-26 and 2014-07-02, profiles are labeled according to Table 2 and Figure 3 (a). Surface elevation changes $(\Delta h)$ between 2000 and 2014 are based on SRTM and TanDEM-X data respectively (b).

glacier fronts but increase with elevation (Figures 2a and 3). For Zepu Glacier an almost linear increase of surface motion is observed, until a maximum is reached approximately $5 \mathrm{~km}$ from the terminus. Then surface velocities remain high up to the end of the valid velocity measurements. For the 2013/2014 period maximum velocities between $60 \mathrm{~m} \mathrm{a}^{-1}$ and $\sim 70 \mathrm{~m} \mathrm{a}^{-1}$ are found in this region (Figure 3). High surface velocities of $\sim 80 \mathrm{~m} \mathrm{a}^{-1}$ are also evident close to the junction of a tributary joining the glacier tongue of Unknown Glacier I from the north (Figure 2a).

To assess multi-annual trends in glacier velocities, longitudinal profiles of yearly average velocities were obtained along the centerlines of the five investigated glaciers (Figure 3). All five glaciers experienced a decrease in 
velocity during the time of investigation. Deceleration of surface velocities affects each glacier tongue, but glaciers differ in the amount of slowing. Along the profiles shown in Figure 3 the highest rate of deceleration between the $1999 / 2003$ period and the 2013/2014 period is observed for Unknown Glacier I. Its average speed decreased by $63 \%$ from $31.79 \mathrm{~m} \mathrm{a}^{-1}$ during the $1999 / 2003$ period to $11.61 \mathrm{~m} \mathrm{a}^{-1}$ during the $2013 / 2014$ period (Table S1). Lowest rates of deceleration are found at Unknown Glacier II. While its average speed was $23.79 \mathrm{~m} \mathrm{a}^{-1}$ during the $1999 / 2003$ period, it slowed down by $43 \%$ to $13.57 \mathrm{~m} \mathrm{a}^{-1}$ during the $2013 / 2014$ period (Table S1). On average, the five investigated glacier tongues slowed down by $51 \%$ between the $1999 / 2003$ period and the 2013/2014 period based on the valid measurements along the centerline profiles shown in Figure 3.

For Unknown Glacier I and Maguolong Glacier the change in surface velocity between the 2008/2009 period and the 2012/2013 period (4 years time difference) is only minor, but is followed by a slowdown between the $2012 / 2013$ period and the $2013 / 2014$ period (1 year time difference) with a similar magnitude as the velocity change between the 1999/2003 period and the 2008/2009 period ( 7 years time difference). By contrast, Zepu Glacier exhibits more consistent deceleration between observations. However, when keeping in mind that the time intervals between the observational periods are not equally spaced, one can assume a more pronounced deceleration in more recent years. Further, it should be noted, that possible variations in glacier velocity between 1999 and 2003 can not be assessed, as the Landsat-derived velocity field is a composite of all available data acquired before the failure of the scanline corrector of Landsat-7 in order to increase the accuracy of the flow field (A. Dehecq, personal communication, March 2016).

Differential analysis of SRTM and TanDEM-X DEMs covering approximately the same time period as the velocity estimates (2000-2014), revealed associated changes in surface elevation. During this time period, the five investigated glaciers show substantial surface lowering with an area-weighted mean of $-0.83 \pm 0.57 \mathrm{~m} \mathrm{a}^{-1}$. With an average rate of $-1.40 \pm 0.57 \mathrm{~m} \mathrm{a}^{-1}$ Guanxing Glacier exhibits the most negative elevation changes of the five investigated glaciers. Conversly, Unknown Glacier I shows the least negative elevation changes of $-0.50 \pm 0.57 \mathrm{~m} \mathrm{a}^{-1}$ on average (Table 2). Most pronounced surface lowering is apparent at the tongue regions of the investigated glaciers. While Zepu Glacier, Unknown Glacier I and Unknown Glacier II show most negative $\Delta h$ values $2.5 \mathrm{~km}$ to $5 \mathrm{~km}$ from the terminus (Figures 3, S2 and S4), Guanxing Glacier and Maguolong Glacier show strongest surface lowering 
near their terminus positions (Figures S3 and S5 respectively). For Guanxing Glacier and Unknown Glacier I strong surface lowering is also evident at the junctions of major tributaries. Even though several accumulation areas yield positive elevation changes, they cannot compensate for the strong mass loss in the ablation areas.

Comparison between the 1999 glacier outlines and the geocoded TanDEM-X master scene from 2014 show only a minor retreat of the glacier terminus positions during the time period of observation. An exception is found for Guanxing Glacier, where a proglacial lake is forming at the glacier terminus (Figure 2b). With a total retreat of 500 m between 1999 and 2014 Guanxing Glacier exhibits the largest terminus retreat of the five investigated glaciers.

Table 2: Glaciers investigated in detail. Glacier names are listed next to the estimated altitude of the Transient snowline (TSL) on 23 September 1999, the corresponding surface area of the accumulation, ablation and glacier area as well as the percentage of debris cover. Further, the mean surface elevation changes $(\overline{\Delta h})$ between 2000 and 2014 are shown.

\begin{tabular}{lcccccc}
\hline Glacier & $\begin{array}{l}\text { TSL } \\
\text { elevation } \\
1999(\mathrm{~m})\end{array}$ & $\begin{array}{l}\text { Accumulation } \\
\text { area }\left(\mathrm{km}^{2}\right)\end{array}$ & $\begin{array}{l}\text { Ablation } \\
\text { area }\left(\mathrm{km}^{2}\right)\end{array}$ & $\begin{array}{l}\text { Glacier } \\
\text { area }\left(\mathrm{km}^{2}\right)\end{array}$ & $\begin{array}{l}\text { Debris- } \\
\text { covered } \\
\text { area }(\%)\end{array}$ & $\overline{\Delta h}\left(\mathrm{~m} \mathrm{a}^{-1}\right)$ \\
\hline Zepu & 4828 & 52.86 & 35.42 & 88.28 & 14 & $-0.58 \pm 0.57$ \\
Unknown I & 4900 & 48.58 & 20.54 & 69.12 & 11 & $-0.50 \pm 0.57$ \\
Unknown II & 4993 & 6.82 & 5.62 & 12.44 & 27 & $-0.67 \pm 0.57$ \\
Maguolong & 5072 & 37.60 & 24.15 & 61.75 & 15 & $-1.19 \pm 0.57$ \\
Guanxing & 5069 & 29.92 & 13.96 & 43.88 & 9 & $-1.40 \pm 0.57$ \\
\hline
\end{tabular}

\section{Discussion}

Throughout the periods of observation, the five debris-covered glacier tongues investigated in this study show evidence of surface motion through to their terminus regions. This finding is contrary to studies in the Himalayas, where many glacier tongues were found to be stagnant (Quincey et al., 2009; Scherler et al., 2011). The fact that surface velocities are measurable through to the glacier terminus suggests extensive accumulation in the higher regions of the investigated glaciers ensuring sufficient ice flux to the glacier tongues. This is in accordance with positive $\Delta h$ values in the highest portions of the accumulation areas, being particularly evident at the large high-altitude plateau of Unknown Glacier I (Figure S4). Even though uncertainties of radar penetration into snow, firn and ice make an in-depth analysis of these effects difficult, the spatial distribution of positive $\Delta h$ values is consistent with expectations regarding regional climate observations. 

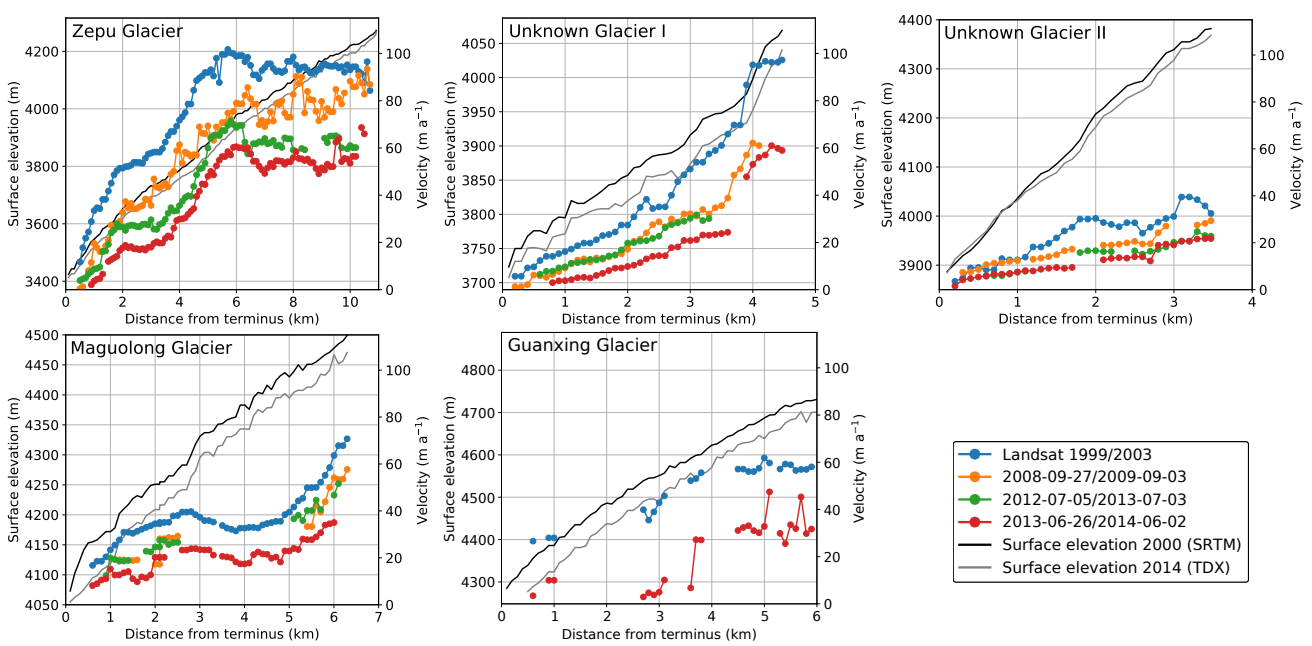

Figure 3: Multi-annual surface velocities and 2000/2014 surface elevations along the centerlines of the five investigated debris-covered glacier tongues (see Figure 2 for the locations of the profiles and Table 2 for details on the glaciers). Landsat-derived surface velocities for the 1999/2003 period are provided by Dehecq et al. (2015). Note, velocities are equally scaled.

Specifically, monsoonal precipitation is very intense (Böhner, 2006; Maussion et al., 2014) and tends to increase in the study region (You et al., 2012; Kim and Park, 2016). At the lower portions of the glaciers monsoonal precipitation falls as rain during summer, potentially enhancing melt in these areas. This is in agreement with findings from nearby Parlung No. 4 Glacier $\left(29.24^{\circ} \mathrm{N}, 96.92^{\circ} \mathrm{E}\right)$, where most rapid melting occurs during the monsoon core season. In this time period the release of latent heat and the energy input from incoming longwave radiation have been shown to have a strong effect on ablation (Yang et al., 2011).

The five debris-covered glacier tongues investigated in this study show a substantial slowdown between the 1999/2003 period and the 2013/2014 period, which is in general agreement with recent glacier deceleration in other parts of High Asia (e.g. Thakuri et al., 2016) and other mountain ranges elsewhere (e.g. Span and Kuhn, 2003; Berthier and Vincent, 2012; Heid and Kääb, 2012). Glacier slowdown was also reported for the neighboring Hailuogou Glacier $\left(29.59^{\circ} \mathrm{N}, 101.95^{\circ} \mathrm{E}\right)$, where the average annual velocity in the ablation area reduced by $24 \%$ between 1981 and 2008 (Zhang et al., 2010). The deceleration of the debris-covered Hailuogou Glacier is in line with our ob- 
servations, which show an average annual deceleration in the ablation area between 18\% and 36\% between the 1999/2003 period and the 2008/2009 period (Table S1). Similar to our results, Hailuogou Glacier shows motion through to its terminus region (Zhang et al., 2010).

The five glaciers investigated in detail show negative average elevation changes between 2000 and 2014. This is in general agreement with large-scale estimates based on ICESat laser altimetry and DEM differencing (Gardelle et al., 2013; Neckel et al., 2014; Kääb et al., 2015). Largest differences are evident when compared to the results of Gardelle et al. (2013) based on DEM differencing. Most of these deviations can be explained by the applied estimates when correcting for C-Band penetration depth. While Gardelle et al. (2013) employed a penetration depth correction of $1.7 \pm 1.5 \mathrm{~m}$, we used a value of $8.5 \pm 1.5 \mathrm{~m}$ following Kääb et al. (2015). Further, the time span between observations is different between both studies. However, our observations agree within their error bars with the ICESat based studies of Neckel et al. (2014) and Kääb et al. (2015) and when applying a C-band penetration depth correction of $1.7 \pm 1.5 \mathrm{~m}$ also with Gardelle et al. (2013).

Glaciers with negative mass balances are known to decelerate as less mass is transported down the glaciers (Heid and Kääb, 2012). This holds true if the accumulation volume is reduced at the glaciers' higher portions. Several studies observed an increase in air temperatures on the Tibetan Plateau during the last decades (e.g. Liu and Chen, 2000; Yang et al., 2014; Duan and Xiao, 2015). This might reduce the extent of accumulation areas, resulting in less snow accumulation and therefore in a decrease of ice flux and hence, surface velocities (Loibl et al., 2014).

Even though all investigated glaciers show negative average elevation changes, except for Guanxing Glacier frontal positions were relatively stable during the period of observation. This indicates that these glaciers are losing mass with only minor terminus retreat, a phenomenon which is well known for debris-covered glaciers (e.g. Benn et al., 2012; Rowan et al., 2015). Our data show that a previous study of Loibl et al. (2014), which applied optical remote sensing to map glacier extents in the same region, underestimates the positions of glacier fronts. This is attributed to the limitations of optical identification of debris-covered stagnant ice areas. Specifically, parts of the tongues, which were previously thought to be decoupled from the main glacier trunk, were still moving according to the velocity data presented here. Detailed investigations of glacier elevation changes revealed strong downwasting for the entire tongues of all investigated glaciers. For Zepu Glacier, 
Unknown Glacier I and Unknown Glacier II maximum elevation changes occurred not directly at the glacier terminus but rather $2.5 \mathrm{~km}$ to $5 \mathrm{~km}$ up glacier (Figures 3, S2 and S4). Such a pattern is known for debris-covered glacier tongues as debris cover thickens down glacier and therefore enhances its insulating effect (Nakawo et al., 1999). This can cause a reduction of the glacier gradient, resulting in a reduction of driving stresses and ice velocities (Quincey et al., 2009; Benn et al., 2012; Rowan et al., 2015). By contrast, Maguolong Glacier shows most negative elevation changes directly at its terminus despite its debris-covered tongue (Figure S5). Such a pattern is most common for clean-ice glaciers and is also found at the less debris-covered Guanxing Glacier (Figure S3). Guanxing Glacier also shows the most negative glacier-averaged elevation changes (Table 2), which can be attributed to two reasons: (1) there is less insulation at the glacier terminus due to missing debris cover and (2) the terminus is directly affected by a proglacial lake (Figure 2b). Both points might also explain the strongest terminus retreat in our study area during the time of observation. Least negative average elevation changes are evident for Unknown Glacier I (Table 2), which can be attributed to the fact that the glacier is fed by a large high-altitude accumulation area (Figure S4).

Overall, our results show substantial downwasting for entire glacier tongues even if they are covered by thick debris. This indicates that for the eastern Nyainqêntanglha Range the frequently observed insulation function of debris cover takes effect on a local scale, but is impaired on a larger scale of entire glacier tongues. In the following, three possible scenarios are briefly discussed which attempt to explain the observed pattern: (1) prominent average surface lowering of debris-covered glaciers might be influenced by thermokarst processes (Kääb et al., 2012). In several studies it has been shown that melting of ice cliffs can significantly contribute to the overall ablation of debris-covered glaciers (Reid and Brock, 2014; Buri et al., 2016). Ice cliffs are present on the investigated glaciers and their melting might contribute to the observed enhanced glacier-averaged surface lowering (Figure S1). (2) A recent modeling study suggests that glacier-averaged surface lowering is smaller for debris-covered glaciers than for clean-ice glaciers at an initial stage of warming (Banerjee, 2017). However, at a more advanced stage of glacier evolution melt rates of debris-covered glaciers equal or even overtake that of clean-ice glaciers due to longer response times. This encourages the assumption, that the investigated glaciers show an advanced stage of negative mass balance. (3) Abundant monsoonal summer rainfall may bypass 
the debris barrier and carries heat to the underlying ice bodies. Laboratory studies suggest that the thickness and permeability of debris cover have a significant effect on the amount of rain-enhanced melt underneath the debris layer (Reznichenko et al., 2010). While the effect beneath medium sand is equal to that of bare ice, thick rock-avalanche debris are able to reduce rainfall enhanced ablation. As heat flux due to precipitation tends to be small for many glaciers, it is often neglected in modeling studies. However, specifically for monsoonal-influenced glaciers, this could be an important heat flux (Reid and Brock, 2010).

While point (1) and (2) can also explain the observed anomaly of debriscovered glaciers in other parts of High Asia (e.g. Kääb et al., 2012; Banerjee, 2017), point (3) is more site-specific, as it requires strong monsoonal rainfall on the lower portions of glaciers. Which of the above mechanisms is the main source for the strong average surface lowering observed in the study region cannot fully be answered by the presented remote sensing dataset requiring further field measurements. However, here we highlight the abundant monsoonal summer rainfall, which may contribute significantly to the regions' high mass losses when compared to predominantly Westerly-influenced regions on the western Tibetan Plateau and in the Pamirs (Yao et al., 2012).

\section{Conclusions}

In this study, new datasets of multi temporal glacier surface velocities and glacier elevation changes were presented for five debris-covered glaciers in the eastern Nyainqêntanglha Range, south-eastern Tibet. The investigated glaciers experienced a significant deceleration between 1999/2003 and 2013/2014, but showed measurable surface velocities through to their terminus positions during all time periods of oberservation. Compared to observations from other regions in High Asia, where most debris-covered glacier tongues show large parts of stagnant ice, this is exceptional. Here, we argue that this is due to intense monsoonal accumulation in the higher glacier regions. By detailed analyses of glacier elevation changes between 2000 and 2014 we observed a reduction of the surface gradient of three glaciers, which can partly be attributed to the spatial distribution of debris cover altering the pattern of glacier melt. Nevertheless we confirm pronounced negative glacier elevation changes in the study region of $-0.83 \pm 0.57 \mathrm{~m} \mathrm{a}^{-1}$ on average. This could be attributed to thermokarst processes or a delayed response time of debris-covered glaciers as observed in other parts of High Asia. Further- 
more, heavy monsoonal summer rainfall may additionally enhance glacier melt in the study region. In order to investigate the contribution of those forcing mechanisms to local glacier mass balances further field measurements are required.

\section{Author contributions}

M. Rankl derived the velocity fields by means of TerraSAR-X feature tracking. N. Neckel calculated the surface elevation changes and did the post processing of the TerraSAR-X velocity fields. D. Loibl conducted GIS analyses. N. Neckel and D. Loibl wrote the manuscript.

\section{Acknowledgements}

N. Neckel and M. Rankl received funding through the HGF Alliance Remote Sensing and Earth System Dynamics. M. Rankl was further supported by the University of Erlangen-Nuremberg and the DLR/BMWi grant FKZ 50E1414. D. Loibl's contribution to this work was supported by the German Research Foundation (Deutsche Forschungsgemeinschaft, DFG) as part of the SPP 1372: Tibetan Plateau - Formation, Climate, Ecosystems. We want to thank A. Dehecq for providing the Landsat velocity field and two anonymous reviewers for improving the manuscript. SRTM and Landsat data were provided by the USGS and TerraSAR-X/TanDEM-X data through Deutsches Zentrum für Luft- und Raumfahrt (DLR) proposals XTI-GLAC0535 and mabra_XTI_GLAC0264.

\section{References}

Banerjee, A., 2017. Brief communication: Thinning of debris-covered and debris-free glaciers in a warming climate. The Cryosphere 11 (1), 133-138. URL http://dx.doi.org/10.5194/tc-11-133-2017

Benn, D., Bolch, T., Hands, K., Gulley, J., Luckman, A., Nicholson, L., Quincey, D., Thompson, S., Toumi, R., Wiseman, S., Aug 2012. Response of debris-covered glaciers in the Mount Everest region to recent warming, and implications for outburst flood hazards. Earth-Science Reviews 114 (12), $156-174$.

URL http://dx.doi.org/10.1016/j. earscirev.2012.03.008 
Berthier, E., Arnaud, Y., Kumar, R., Ahmad, S., Wagnon, P., Chevallier, P., 2007. Remote sensing estimates of glacier mass balances in the Himachal Pradesh (Western Himalaya, India). Remote Sensing of Environment 108 (3), 327-338.

Berthier, E., Arnaud, Y., Vincent, C., Remy, F., Apr. 2006. Biases of SRTM in high-mountain areas: Implications for the monitoring of glacier volume changes. Geophys. Res. Lett. 33 (8), 5.

URL http://dx.doi.org/10.1029/2006GL025862

Berthier, E., Vincent, C., 2012. Relative contribution of surface mass-balance and ice-flux changes to the accelerated thinning of Mer de Glace, French Alps, over 1979-2008. Journal of Glaciology 58 (209), 501-512.

URL http://dx.doi.org/10.3189/2012JoG11J083

Böhner, J., 2006. General climatic controls and topoclimatic variations in Central and High Asia. Boreas 35 (2), 279-295.

Buri, P., Pellicciotti, F., Steiner, J. F., Miles, E. S., Immerzeel, W. W., 2016. A grid-based model of backwasting of supraglacial ice cliffs on debriscovered glaciers. Annals of Glaciology 57 (71), 199-211.

URL http://dx.doi.org/10.3189/2016AoG71A059

Copland, L., Pope, S., Bishop, M. P., Shroder, J. F., Clendon, P., Bush, A., Kamp, U., Seong, Y. B., Owen, L. A., 2009. Glacier velocities across the central Karakoram. Annals of Glaciology 50, 41-49.

Cuffey, K. M., Paterson, W. S. B., 2010. The physics of glaciers. ButterworthHeineman, Oxford.

Dehecq, A., Gourmelen, N., Trouve, E., 2015. Deriving large-scale glacier velocities from a complete satellite archive: Application to the PamirKarakoram-Himalaya. Remote Sensing of Environment 162, 55-66.

URL http://dx.doi.org/10.1016/j.rse.2015.01.031

Duan, A., Xiao, Z., 2015. Does the climate warming hiatus exist over the Tibetan Plateau? Scientific Reports 5, 9.

Farr, T. G., Rosen, P. A., Caro, E., Crippen, R., Duren, R., Hensley, S., Kobrick, M., Paller, M., Rodriguez, E., Roth, L., Seal, D., Shaffer, S., Shimada, J., Umland, J., Werner, M., Oskin, M., Burbank, D., Alsdorf, 
D., 2007. The Shuttle Radar Topography Mission. Rev. Geophys. 45 (2), RG2004.

URL http://dx.doi.org/10.1029/2005RG000183

Gardelle, J., Berthier, E., Arnaud, Y., 2012. Impact of resolution and radar penetration on glacier elevation changes computed from DEM differencing. Journal of Glaciology 58 (208), 419-422.

Gardelle, J., Berthier, E., Arnaud, Y., Kääb, A., 2013. Region-wide glacier mass balances over the Pamir-Karakoram-Himalaya during 1999-2011. The Cryosphere 7 (4), 1263-1286.

URL http: //www . the-cryosphere.net/7/1263/2013/

Heid, T., Kääb, A., 2012. Repeat optical satellite images reveal widespread and long term decrease in land-terminating glacier speeds. The Cryosphere $6(2), 467-478$.

URL http://www . the-cryosphere.net/6/467/2012/

Hochreuther, P., Loibl, D., Wernicke, J., Zhu, H., Grießinger, J., Bräuning, A., 2015. Ages of major little ice age glacier fluctuations on the southeast tibetan plateau derived from tree-ring-based moraine dating. Palaeogeography, Palaeoclimatology, Palaeoecology 422, 1-10.

Höhle, J., Höhle, M., 2009. Accuracy assessment of digital elevation models by means of robust statistical methods. ISPRS Journal of Photogrammetry and Remote Sensing 64 (4), 398-406.

Holzer, N., Vijay, S., Yao, T., Xu, B., Buchroithner, M., Bolch, T., 2015. Four decades of glacier variations at Muztagh Ata (eastern Pamir): a multisensor study including Hexagon KH-9 and Pléiades data. The Cryosphere 9 (6), 2071-2088.

URL http://www.the-cryosphere.net/9/2071/2015/

Huang, M., 1990. On the temperature distribution of glaciers in China. Journal of Glaciology 36, 210-216.

Kääb, A., 2005. Combination of SRTM3 and repeat ASTER data for deriving alpine glacier flow velocities in the Bhutan Himalaya. Remote Sensing of Environment 94, 463474. 
Kääb, A., Berthier, E., Nuth, C., Gardelle, J., Arnaud, Y., 2012. Contrasting patterns of early twenty-first-century glacier mass change in the Himalayas. Nature 488 (7412), 495-498.

URL http://dx.doi.org/10.1038/nature11324

Kääb, A., Treichler, D., Nuth, C., Berthier, E., 2015. Brief Communication: Contending estimates of 2003-2008 glacier mass balance over the PamirKarakoram-Himalaya. The Cryosphere 9 (2), 557-564.

URL http://dx.doi .org/10.5194/tc-9-557-2015

Kim, J., Park, S. K., 2016. Uncertainties in calculating precipitation climatology in East Asia. Hydrology and Earth System Sciences 20 (2), 651-658.

Liu, X., Chen, B., 2000. Climatic warming in the Tibetan Plateau during recent decades. International Journal of Climatology 20 (14), 1729-1742.

Loibl, D., Hochreuther, P., Schulte, P., Hülle, D., Zhu, H., Bräuning, A., Lehmkuhl, F., 2015. Toward a late Holocene glacial chronology for the eastern Nyainqêntanglha Range, southeastern Tibet. Quaternary Science Reviews 107, 243-259.

Loibl, D., Lehmkuhl, F., Grießinger, J., 2014. Reconstructing glacier retreat since the Little Ice Age in SE Tibet by glacier mapping and equilibrium line altitude calculation. Geomorphology 214, 22-39.

Loibl, D. M., Lehmkuhl, F., 2015. Glaciers and equilibrium line altitudes of the eastern Nyainqêntanglha Range, SE Tibet. Journal of Maps 11 (4), $575-588$.

URL http://dx.doi.org/10.1080/17445647.2014.933451

Lopez, M., Berry, J., 2002. Use Surface Area for Realistic Calculations. GeoWorld, 22-23.

Maussion, F., Scherer, D., Mölg, T., Collier, E., Curio, J., Finkelnburg, R., 2014. Precipitation Seasonality and Variability over the Tibetan Plateau as Resolved by the High Asia Reanalysis. J. Climate 27 (5), 1910-1927. URL http://dx.doi .org/10.1175/JCLI-D-13-00282.1

Mcnabb, R., Hock, R., ONeel, S., Rasmussen, L., Ahn, Y., Braun, M., Conway, H., Herreid, S., Joughin, I., Pfeffer, W., et al., Dec 2012. Using surface velocities to calculate ice thickness and bed topography: a case study at 
columbia glacier, alaska, USA. Journal of Glaciology 58 (212), 11511164. URL http://dx.doi.org/10.3189/2012JoG11J249

Nakawo, M., Yabuki, H., Sakai, A., 1999. Characteristics of Khumbu Glacier, Nepal Himalaya: recent change in the debris-covered area. Annals of Glaciology 28, 118-122.

Neckel, N., Braun, A., Kropáček, J., Hochschild, V., 2013. Recent mass balance of the Purogangri Ice Cap, central Tibetan Plateau, by means of differential X-band SAR interferometry. The Cryosphere 7 (5), 1623-1633. URL http://www. the-cryosphere.net/7/1623/2013/

Neckel, N., Kropáček, J., Bolch, T., Hochschild, V., 2014. Glacier mass changes on the Tibetan Plateau 2003 - 2009 derived from ICESat laser altimetry measurements. Environmental Research Letters 9 (1), 014009. URL http://stacks.iop.org/1748-9326/9/i=1/a=014009

Östrem, G., 1959. Ice melting under a thin layer of moraine, and the existence of ice cores in moraine ridges. Geografiska Annaler 41 (4), 228-230. URL http: //www . jstor .org/stable/4626805

Paul, F., Bolch, T., Kääb, A., Nagler, T., Nuth, C., Scharrer, K., Shepherd, A., Strozzi, T., Ticconi, F., Bhambri, R., et al., 2015. The glaciers climate change initiative: Methods for creating glacier area, elevation change and velocity products. Remote Sensing of Environment 162, 408-426. URL http://dx.doi.org/10.1016/j.rse.2013.07.043

Quincey, D. J., Braun, M., Glasser, N. F., Bishop, M. P., Hewitt, K., Luckman, A., Sep 2011. Karakoram glacier surge dynamics. Geophysical Research Letters 38 (18), 6.

URL http://dx.doi.org/10.1029/2011GL049004

Quincey, D. J., Luckman, A., Benn, D., 2009. Quantification of Everest region glacier velocities between 1992 and 2002, using satellite radar interferometry and feature tracking. Journal of Glaciology 55, 596-606.

Rabus, B., Eineder, M., Roth, A., Bamler, R., 2003. The shuttle radar topography mission - a new class of digital elevation models acquired by spaceborne radar. ISPRS Journal of Photogrammetry and Remote Sensing 57 (4), 241-262. 
Rankl, M., Braun, M., 2016. Glacier elevation and mass changes over the central Karakoram region estimated from TanDEM-X and SRTM/X-SAR digital elevation models. Annals of Glaciology 51 (71), 273-281.

Rankl, M., Kienholz, C., Braun, M., 2014. Glacier changes in the Karakoram region mapped by multimission satellite imagery. The Cryosphere 8 (3), 977-989.

URL http://www.the-cryosphere.net/8/977/2014/

Reid, T., Brock, B., 2014. Assessing ice-cliff backwasting and its contribution to total ablation of debris-covered Miage glacier, Mont Blanc massif, Italy. Journal of Glaciology 60 (219), 3-13.

URL http://dx.doi.org/10.3189/2014JoG13J045

Reid, T. D., Brock, B. W., 2010. An energy-balance model for debris-covered glaciers including heat conduction through the debris layer. Journal of Glaciology 56 (199), 903-916.

URL http://dx.doi.org/10.3189/002214310794457218

Reznichenko, N., Davies, T., Shulmeister, J., McSaveney, M., Aug. 2010. Effects of debris on ice-surface melting rates: an experimental study. Journal of Glaciology 56, 384-394.

Rignot, E., Echelmeyer, K., Krabill, W., 2001. Penetration depth of interferometric synthetic-aperture radar signals in snow and ice. Geophys. Res. Lett. 28 (18), 3501-3504.

URL http://dx.doi.org/10.1029/2000GL012484

Rowan, A. V., Egholm, D. L., Quincey, D. J., Glasser, N. F., 2015. Modelling the feedbacks between mass balance, ice flow and debris transport to predict the response to climate change of debris-covered glaciers in the Himalaya. Earth and Planetary Science Letters 430, 427-438.

Scherler, D., Bookhagen, B., Strecker, M. R., 2011. Spatially variable response of Himalayan glaciers to climate change affected by debris cover. Nature 1068, 4.

Scherler, D., Leprince, S., Strecker, M. R., 2008. Glacier-surface velocities in alpine terrain from optical satellite imagery-accuracy improvement and quality assessment. Remote Sensing of Environment 112 (10), 3806-3819. URL http://dx.doi.org/10.1016/j.rse.2008.05.018 
Seehaus, T., Marinsek, S., Helm, V., Skvarca, P., Braun, M., 2015. Changes in ice dynamics, elevation and mass discharge of Dinsmoor-BombardierEdgeworth glacier system, Antarctic Peninsula. Earth and Planetary Science Letters 427, 125135.

URL http://dx.doi.org/10.1016/j.epsl.2015.06.047

Shi, Y., Mi, D., Yao, T., Zeng, Q., Liu, C., 2010. Glaciers of China. In: Williams, R.S., J., Ferrigno, J. (Eds.), Glaciers of Asia. U.S. Geological Survey professional paper 1386-F-2.

Shih, Y., Hsieh, T., Cheng, P., Li, C., 1980. Distribution, features and variations of glaciers in China. In: Proceedings of the Riederalp Workshop, Sep. 1978.

Span, N., Kuhn, M., 2003. Simulating annual glacier flow with a linear reservoir model. Journal of Geophysical Research 108 (D10), 9.

URL http://dx.doi.org/10.1029/2002JD002828

Thakuri, S., Salerno, F., Bolch, T., Guyennon, N., Tartari, G., 2016. Factors controlling the accelerated expansion of Imja Lake, Mount Everest region, Nepal. Annals of Glaciology 57 (71), 245-257.

Wei, Y., Tandong, Y., Baiqing, X., Hang, Z., 2010. Influence of supraglacial debris on summer ablation and mass balance in the $24 \mathrm{k}$ Glacier, southeast Tibetan Plateau. Geografiska Annaler: Series A, Physical Geography 92 (3), 353-360.

URL http://dx.doi.org/10.1111/j.1468-0459.2010.00400.x

Yang, K., Wu, H., Qin, J., Lin, C., Tang, W., Chen, Y., 2014. Recent climate changes over the Tibetan Plateau and their impacts on energy and water cycle: A review. Global and Planetary Change 112, 79-91.

Yang, W., Guo, X., Yao, T., Yang, K., Zhao, L., Li, S., Zhu, M., 2011. Summertime surface energy budget and ablation modeling in the ablation zone of a maritime Tibetan glacier. Journal of Geophysical Research 116 (D14), 11 .

Yao, T., Thompson, L., Yang, W., Yu, W., Gao, Y., Guo, X., Yang, X., Duan, K., Zhao, H., Xu, B., Pu, J., Lu, A., Xiang, Y., Kattel, D. B., Joswiak, D., 2012. Different glacier status with atmospheric circulations in 
631 Tibetan Plateau and surroundings. Nature Clim. Change 2 (9), 663-667.

${ }_{632}$ URL http://dx.doi.org/10.1038/nclimate1580

${ }_{633}$ You, Q., Fraedrich, K., Ren, G., Ye, B., Meng, X., Kang, S., 2012. Inconsistencies of precipitation in the eastern and central Tibetan Plateau between surface adjusted data and reanalysis. Theoretical and Applied Climatology $636 \quad 109(3-4), 485-496$.

Zhang, Y., Fujita, K., Liu, S., Liu, Q., Wang, X., 2010. Multi-decadal icevelocity and elevation changes of a monsoonal maritime glacier: Hailuogou glacier, China. Journal of Glaciology 56 (195), 65-74.

${ }_{640}$ URL http://dx.doi.org/10.3189/002214310791190884 